\title{
Time-variable frequency of events in domains of Tilia cambium
}

\author{
WIESLAW WLOCH
}

Department of Biophysics and Cell Biology, Silesian University, Jagiellońska 28, 40-032 Katowice, Poland

(Received: April 20, 1984. Accepted: June 25, 1984)

\begin{abstract}
In the cambium of linden, producing xylem with interlocked grain, domains active, as regards the occurrence of events, and inactive ones can be distinguished. The area of the cambium investigated was an assemblage of small domains among which at certain periods domains $\mathrm{Z}$, and, at another period, domains $\mathrm{S}$ were active. The inclination of the grain was changing in the direction corresponding to the type of the active domains. Alternative occurrence of periods of activity of $\mathrm{Z}$ and $\mathrm{S}$ domains led to the formation of interlocked grain in the xylem, with a much longer wave than the height of a pair domains.
\end{abstract}

Key words: cambium, domain pattern, interlocked grain, cambial activity

\section{INTRODUCTION}

The cambium has a domain pattern (Hejnowicz 1964, 1973, 1975, Hejnowicz and Krawczyszyn 1969, Hejnowicz and Romberger 1973, 1979, Krawczyszyn 1971, 1972, 1973, Pyszyński 1977). Domains are regions where cellular events occur in only one configuration, either "right" or "left". Thus, two types of domain can be distinguished: Z-ones (where the events run in "to the right" configuration) and S-ones (where the events run in "to the left" configuration). In nonstroreyed cambium the following oriented events occur: 1) overlapping of intrusively growing cell ends, 2) pseudotransverse anticlinal division, 3) splitting of rays by intrusively growing fusiform cells, 4) elimination of fusiform cell strand between two rays, owing to which uniting of rays occurs. The domain pattern shifts at a definite rate which is the higher the longer domains are. The period of existence of one type of domain at a given site shows a low variability in spite of high variability of domain length in the cambia of various trees 
(Hejnowicz 1975). Pulsation of domain length may occur (Hejnowicz 1974). Hejnowicz $(1973,1975)$ advanced the hypothesis that the domain patterns are a manifestation of propagated waves of orientational tendency characterized by invariant period and variable length and velocity. In the same cambium waves of different lengths may coexist, which, as the result of superposition, may cause pulsations of the domain height and lead to the development of characteristic types of xylem grain (Hejnowicz and Romberger 1979).

In the case of storeyed cambium there are practically no intrusive growth or pseudotransverse anticlinal divisions. The modification of the cell inclination is possible owing to the occurrence of limited intrusive growth which repeatedly produces a new pointed tip to one side of the existing tip which then is eliminated. A transient forking of the tip occurs. The tips of one storey creep past those of the adjoining storey, the opposite tips of a fusiform cell creep in opposite directions so that the cell rotates slightly about its center (Hejnowicz and Zagórska-Marek 1974, Zagórska-Marek 1975, 1983, Krawczyszyn and Romberger 1979, Włoch and Zagórska-Marek 1982).

The oriented events of sufficient frequency produce a change in the inclination of the cells in relation to the stem axis. When domains are short curly grain in the wood is developing. When domain height is high and their movement along the stem is rapid interlocked grain is developing (Hejnowicz 1971, 1973, Hejnowicz and Romberger 1973, 1979, Krawczyszyn 1972, Pyszyński 1977).

To-date investigations of the domain pattern indicate that the frequency of events may change with time (Hejnowicz 1968, Zagórska-Marek 1975, Włoch and Zagórska-Marek 1982). The question arises, whether this variability concerns to the same degree both types of domains, or whether it is dependent on the kind of domain. This problem was studied on linden cambium as model.

The linden is a tree characterised by the occurrence of storeyed cambium with nonstoreyed arrangement of rays. Sometimes, however, in some trees there may be a tendency to storey of disposition of the rays (Wloch and Zagórska-Marek 1982).

In the stems of old lindens interlocked grain appears locally. Xylem with such grain is found in many species as a characteristic feature, as for instance in Entandrophragma (Hejnowicz and Zagórska-Marek 1974) and in Platanus (K r awczy sz y n 1971, 1972). In these two trees interlocked grain is the manifestation of a domain pattern with high, rapidly shifting domains in the cambium showing a high frequency of events. It may be pressumed that interlocked grain in the linden xylem develops on a similar principle. In the case of linden the type of domain and intensity of oriented events can be established on the basis of splitting and uniting 
of rays. Preliminary investigation indicated that these events in the region characterized by interlocked grain in the xylem appear periodically, occurring once in the Z-domains and again in the S-ones.

\section{MATERIAL AND METHODS}

The object of investigation were fragments taken from the stem of a linden (Tilia cordata Mill.) about 100 years old. Samples of wood were collected at breast height of the felled tree not containing any more living cambium. On the surface of the wood waviness of the grain could be seen. The lentgh of the segment on which the cycle of the waviness took place was about $1 \mathrm{~m}$. Wood samples about $1.3 \mathrm{~cm}$ long and $0.5 \mathrm{~cm}$ wide, comprising $6 \mathrm{~cm}$ of radial dimension were taken for microscopic study. The radial dimension included latest 40 annual growth increments.

The wood samples were put alternatively into boiling and cold water for removal of air, and then cut on a sliding microtome into series of $40 \mu \mathrm{m}$ sections. The sections were dehydrated and embedded in Canadian balsam on an object glass. The series of sections comprised 40 annual increments. The investigations consisted in comparison of the terminal xylem in the successive increments. Photographs of the sections containing terminal xylem were made directly on photographic paper with the use of a Zeiss "Documator". By comparing the successive photographs the uniting and splitting of rays could be detected.

For supplementation of the data cambium samples were collected in June from another old linden (Tilia cordata Mill.). They were fixed in glutaraldehyde, dehydrated in an acetone gradient, embedded in epon, cut on the ultramicrotome into semithin sections and stained by the PAS method. The sections were embedded in Euparal.

\section{RESULTS}

Cambium from the examined linden is characterised by the presence of two kinds of rays: 1) multiseriate ones of the height of one or more fusiform cell storeys, and 2) uniseriate short ones of height less than one storey (Fig. 1). Uniting and splitting of rays concerned only the multiseriate rays.

Uniting and splitting of rays is shown in Figs. 2 and 3. It is seen in Fig. 2 that the neighbouring cell tips pointing in opposite directions at the boundary of storeys migrate in ipposite directions, causing inclination of the cells to the right. The multiseriate ray undergoes at the boundary 
splitting of Z-type into two shorter rays within the range of the storeys, which continue to incline together with the fusiform cells. The centres of the rays do not change their original position. It was noted that the direction of changing the ray inclination is in agreement with the direction of the creep of fusiform tips in neighbourhood of the studied rays and the rate of the changing was proportional to the rate of the creep, thus the changing of ray inclination can be used as indicator of the occurrence of more basic oriented events in the cambium.
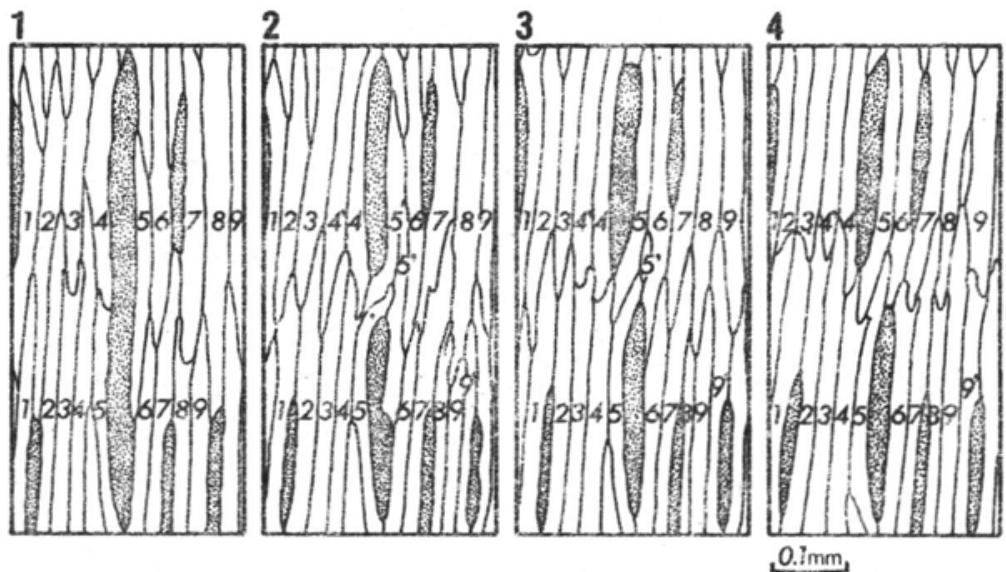

Fig. 2. Series of cambium drawings reproduced for four successive boundaries (layers of terminal xylem) of annual rings. The series shows the way of creeping of cell tips of one storey past those of the adjoining storey and the way of ray splitting. Fusiform cells of one storey are denoted by successive numbers. The grain becomes inclined in Z-direction

The. events (uniting and splitting of rays) identified in one of the examined samples are shown in Figs. 4 and 5. The maps in Fig. 4 record all events which occurred in the given period on the rectangular area shown. The $\mathrm{Z}$ and $\mathrm{S}$ types of events are denoted by clear and full symbols respectivelly. Figure 5 presents in diagrammatic form the events occurrence on the same area as that shown in Fig. 4.

In the period discussed as example a change in the type of events is observed on the successive maps. Maps 2-6 show, almost exclusively events of type $S$, only two events of type $Z$ are seen in map 4. In maps 7-11 events of both types are present, although there is a slight prevaience of type $S$ events. In maps 12-16 the events are once more almost exclusively of $\mathrm{S}$ type. Map 17 is blank, in the corresponding period, namely, no event occurred on the examined area. Maps 18 and 19 contain a small number of events of both types. $\mathrm{Z}$ type events appear almost exclusively in maps 20-25. In maps 26 and 27 a small number of events of both types may be seen. Maps 28-36 (9 years) 




Fig. 1. Tangential section through linden cambium with nonst oreyed arrangement of multiseriate ràs 

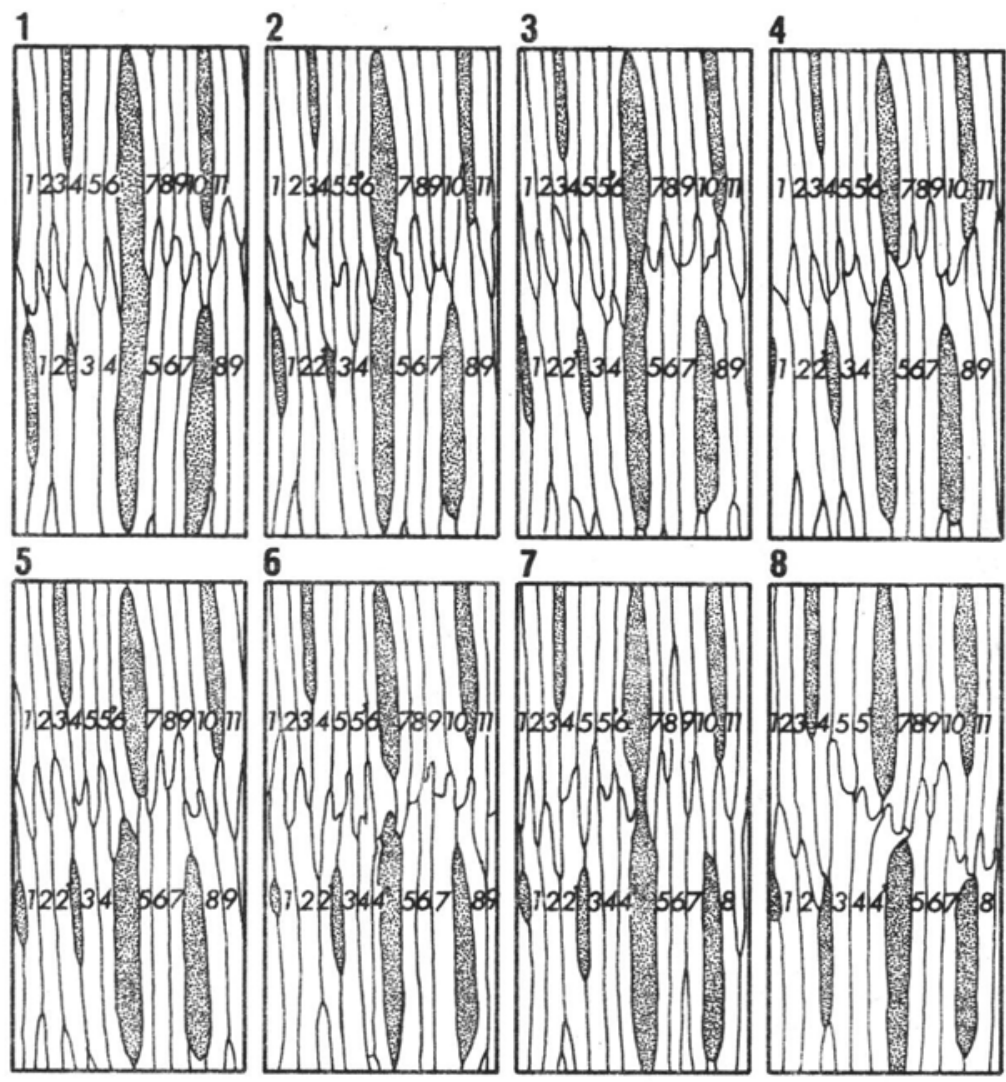

$0.1 \mathrm{~mm}$

Fig. 3. Series of darwings of the same cambial area at eight successive boundaries of annual rings. Splitting of cental ray in configuration $S$ is visible, then uniting of parts of this ray in configuration $Z$ and splitting in configuration $Z$. These ray events are accompanied by changes in contacts between tips of fusiform cells of two storeys

indicate events of type $\mathrm{S}$. Then, for a short time of two years (maps 37-38) Z-type events occur, and further, once more, numerous type $\mathrm{S}$ ones in the course of one year (map 39). The wide differences in the occurrence of the events and their nonuniform distribution should be noted. If the examined area were treated as contained in one domcin, we would reach the conclusion that the duration of domains in this area varies, from one year to 15 years. Further investigations, however, demonstrated that the studied area is not comprised in one domain.

Before elucidating this problem, let us consider the occurrence of events in relation to their kind (uniting and splitting) beside their directional type. In the example here discussed, in maps 2-5 uniting is mainly of type $\mathrm{S}$, next come mainly splittings of type $S$ (maps 6-8), further, after a period 


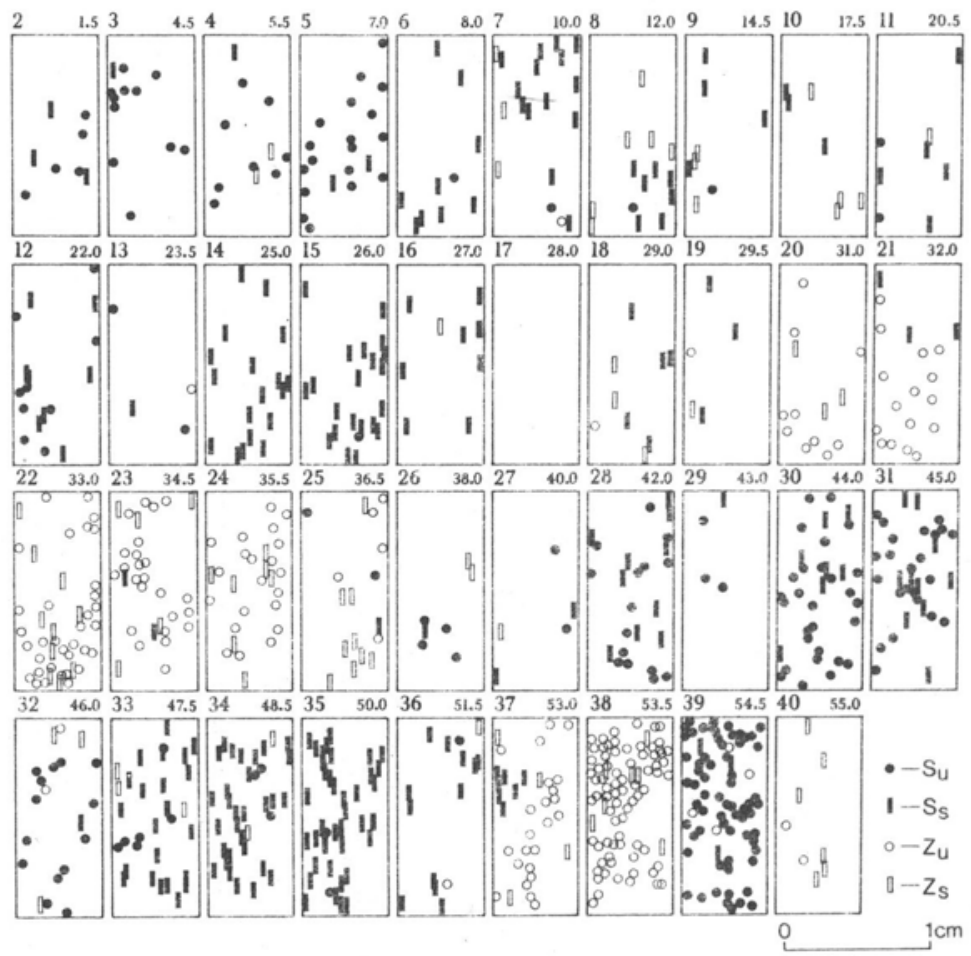

Fig. 4. Maps showing uniting and sphttung of rays during the formation of 40 successive annual rings. A map denoted by figure $\mathrm{m}$ at upper left corner is obtained from the comparison of terminal xylem of annual ring $\mathrm{n}+\mathrm{m}$ with terminal xylem of previous ring, where $\mathrm{n}$ is about 60 . The figure in upper right corner denotes the distance of the outer border of the currently examined annual ring. All events concerning the rays on the examined area have been taken into account, however, if three superposed small rays were united or one ray was split into three parts this was considered as a single event. $S_{u}-$ uniting of type $S, S_{s}-$ splitting of type $S, Z_{u}-$ uniting of type $Z, Z_{s}-$ splitting of type $\mathrm{Z}$

of splittings of both types (maps 9-11) there appear splitting of type S. In maps 20-24 uniting of type $Z$ dominates, then splitting of type $Z$ (map 25) and further again uniting and splitting of type $S$ (maps 28-32 and 33-36). Thus, there is such a situation that in a period of occurrence of events of one type, there appears, after a time of uniting, a time of ray splitting. Such a sequence of events is understandable. However, from the moment marked in map 38 something exceptional happens. In the latter map, namely, uniting of $\mathrm{Z}$ type is frequent, whereas in the next map (39) $\mathrm{S}$ type uniting appears more often. Thus, a change has occurred in the type of events, without change in their kind. Uniting of type $S$ in map 39 did not occur after splitting of type $\mathrm{Z}$, as could have been expected in a normal sequence of the type and kind of events. With 151 cases of uniting on 
both maps, there were only 10 splittings. In the next year (map 40) splitting was of type $\mathrm{Z}$, but with a low density. One might suppose that pulsation of domain may have occurred here, that is, the edge of a large domain would have suddenly encompassed the area which belonged to another domain. A more detailed analysis of the examined area, however, points to a different phenomenon.

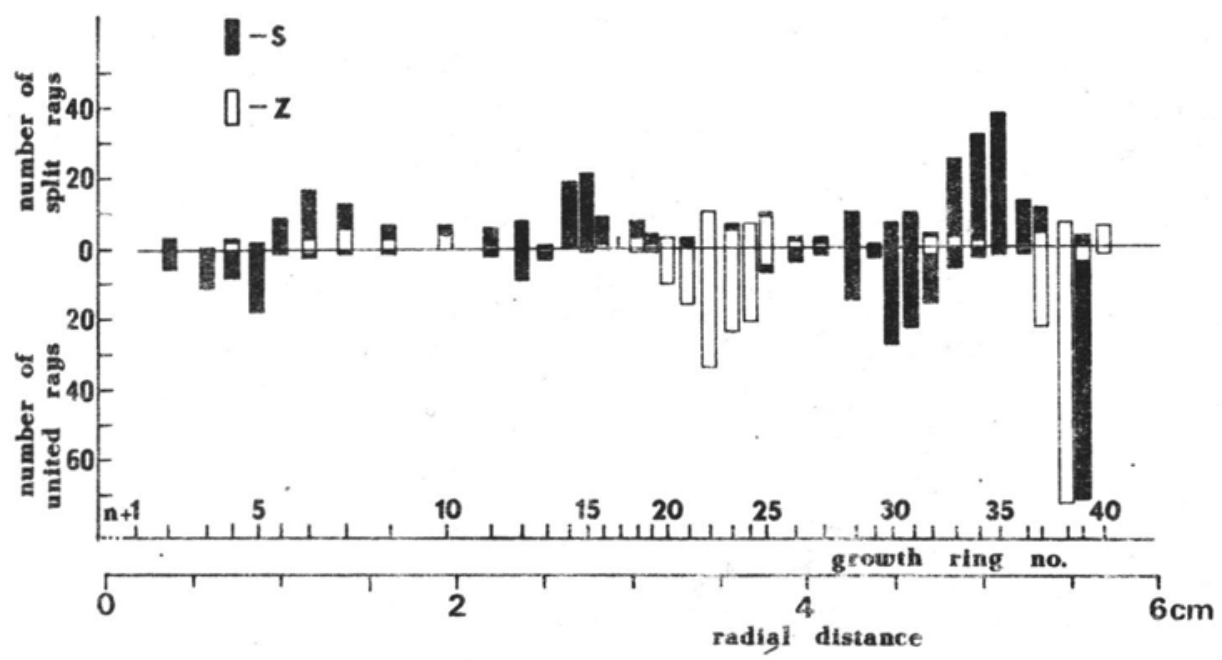

Fig. 5. Diagram showng the events during formation of 40 annual rings on the same cambial area as that in Fig. 4. The lower scale indicates the radial position with respect to the position of the ring $\mathrm{n}+1$, where $\mathrm{n}$ is about 60 . The diametre of the stem was $40 \mathrm{~cm}$

All rays from the terminal xylem of the annual ring no. $n+37$ undergoing events in two subsequent years are shown in Fig. 6 taking into account the strict localization of the rays. Rays which will unite in the year " 38 " according to type $\mathrm{Z}$ and those which will unite in the year "39" according to type $S$ are distinctly seen to occupy different areas, they are clearly separated. These areas supplement each other. In other words, on both the maps examined active areas (with uniting of rays) and inactive ones could be distinguished. Between the areas active in the year " 38 " and in which uniting of $\mathrm{Z}$ type occurred, there appeared inactive areas. In the next year the situation was reversed, in the previously inactive areas numerous cases of type $S$ uniting appeared. Within the examined area there occurred a change in the domain activity, but not a change of its type. It, thus, results that the studied area is not a fragment of a large domain but an assemblage of small domains. It seems that the domains are delimited by boundaries between active and inactive areas. If it actually is so, we are dealing with small, thus slowly moving domains, 
among which at a certain period domains $\mathrm{Z}$, at other times domains $\mathrm{S}$ are active. The presence of active domains of solely $Z$ (S) type on a larger cambium surface, with a high frequency of events, causes inclination of cells in $\mathrm{Z}$ (S) direction on this area. The activity alternating in time causes a periodical change of cell inclination. The arrangement of cambial cells is then preserved in the xylem in the form of interlocked grain.

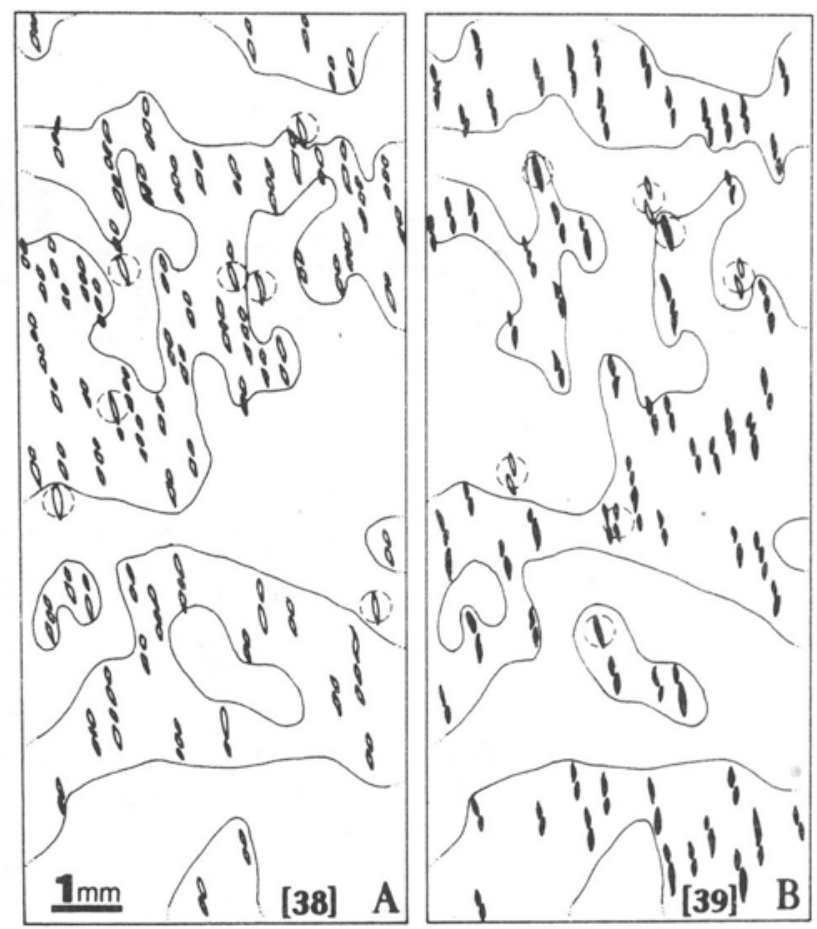

Fig. 6. Maps showing the rays in terminal xylem of the ring 37 which underwent modifications (uniting or splitting) in the next two annual rings -38 and 39 . Rays which underwent $\mathrm{S}$ events are denoted as full, those with $\mathrm{Z}$ events are clear.

A - rays which underwent modification in the ring 38. Most of them united according to type $Z$ (denoted as pairs before uniting). Several rays split according to type $Z$ (circumscribed by dashed line). There were no events of $\mathrm{S}$ type in this ring. Areas of $\mathrm{Z}$ uniting are surrounded by line. B - rays which underwent modification in the ring 39. Most of them united according to type S. Four cases of type $Z$ uniting and three splittings of type $\mathrm{S}$ were noted (circumscribed by dashed line). The borders of the areas of $\mathrm{Z}$ uniting in year 38 are redrawn

The model of small domains and different activity in both types of domain on the studied area is shown schematically in radial plane in Fig. 7 on the assumption that the period $\mathrm{T}$ of the propagated wave of orientational tendency corresponds to time from map 18 to map 39 of the Fig. 4. During this time on the considered area the dominant 
type of events changed three times. The two intervals of prevalence of activity of only one type of domains, $18-25$ and 26-36, were rather long lasting and the whole investigated area may be treated mistakenly as much smaller than a single domain. One might suppose that during the first interval there was a $\mathrm{Z}$ domain in the area, then at " 25 " year the border between two domains was shifting through the area and in the second interval the area belonged to a $\mathrm{S}$ domain. The situation becomes clear, however, when we take into account the distribution of events of opposite types on spatially separated areas, and the occurrence of short lasting interval of prevalence of Z-type activity 36-38. The here presented model explains the high variability of duration of a given type of events on a large cambium surface, with constant rate of shifting of domains of a definite length.

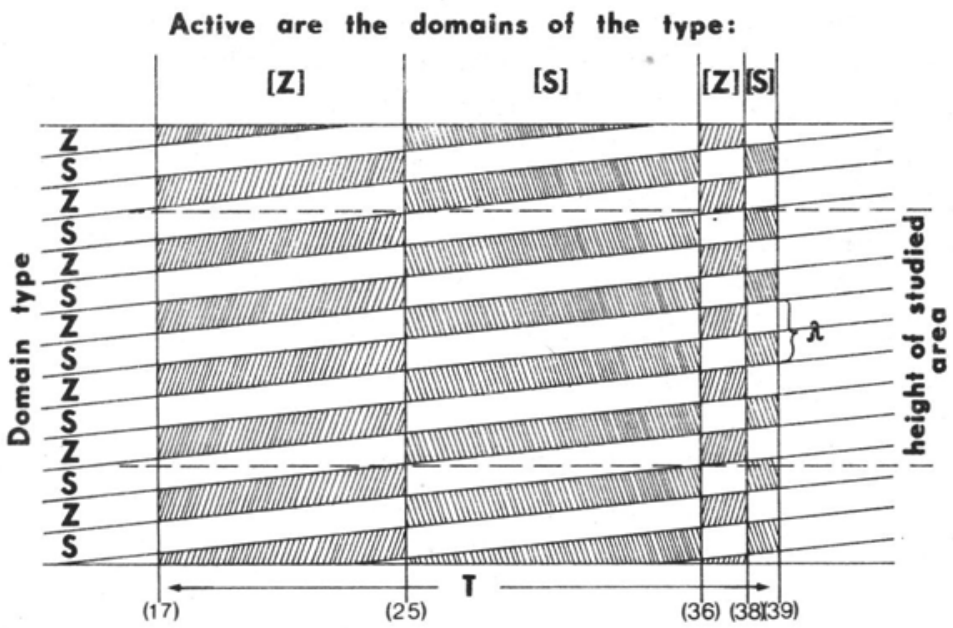

Fig. 7. Model of unidimensional domain pattern with domain height $\left(\frac{\lambda}{2}\right)$ corresponding to mean height of domains in the studied linden, moving at a rate $\mathrm{v}=\left(\frac{\lambda}{2}\right)$, where the period $\mathrm{T}$ is assumed to amount to 22 years. Periods of activity of one domain type are marked, active domains are denoted by hatching. During the time of one period a change of type of the active domain occurred three times in accordance with the Figs. 4 and 5

\section{DISCUSSION}

It was remarked in the present study that the different frequency of events and their nonuniform distribution on the investigated areas may result from the unequal activity of the domains. In most papers devoted to the investigation of domain patterns differences in frequency and nonuniform distribution of events may be observed (Hejnowicz 1968, Hejnowicz and Romberger 1973, Krawczyszyn 1971). This is best 
visible in the domain pattern of Fraxinus (Hejnowicz 1974) and Aesculus (Pyszyński 1977), however, not much attention was paid to this phenomenon. In the cases of Fraxinus and Aesculus, on the investigated area in a certain period a lower frequency of events may be noted in domains of the same type. One may, therefore, affirm that in the above named cases there appeared areas more or less active, corresponding to domains of a definite type. The presence of active and inactive domains may also be seen on drawings of the creeping of fusiform cell tips in storeyed cambium (Hejnowicz and Zagórka-Marek 1974). Zagórska-Marek (1975, 1983) and Włoch and Zagórska-Marek (1982) affirm this explicite indicating that the same area studied in the successive annual increments is once active and the next time inactive.

The present paper reveals a highly variable in time activity of appearance of events of a definite type. If we assume the period of activity of one type of domains as the duration time of one domain at a locus, the conclusion of Hejnowicz (1975) that the cambial morphogenic waves are invariant in period would not be correct. This conclusion, however, remains true when the period of morphogenic waves is distinguished from periodicity in the activity of domains of one type. Zagórska-Marek (1981), while observing the active and inactive areas on the example of cambium activity in Entandrophragma advances the supposition that in storeyed cambium migrating "domain micropatterns" occur with a period much shorter than the invariant period of the cambial morphogenic waves. The character of the domain pattern expressed in the frequency of events, or in the activity of different domains, seems to be highly variable. This character would concern solely the amplitude of the cambial morphogenic waves but not their period.

The present investigations indicate that the amplitude of the cambial morphogenic waves is the function of the type of domain and of time. The results here presented also seem to indicate that interlocked grain characterized by a long "wave" on the tangential surface of an annual ring may be based on a pattern of domains much shorter than the wavelength of the grain.

Acknowledgment

The author is deeply grateful to Professor Zygmunt Hejnowicz for his valuable advice and critical comments in the course of this work.

\section{REFERENCES}

Hejnowicz Z., 1964. Orientation of te partition in pseudotransverse division in cambia of some conifers. Can. J. Bot. 42:1685-1691. 
Hejnowicz Z., 1968. The structural mechanism involved in the changes of grain in timber. Acta Soc. Bot. Pol. 37: 347-365.

Hejnowicz Z., 1971. Upward movement of the domain pattern in the cambium producing wavy grain in Picea excelsa. Acta Soc. Bot. Pol. 40: 499-512.

Hejnowicz Z., 1973. Morphogenetic waves in cambia of trees. Plant Sci. Let. 1: 359-366. Hejnowicz Z., 1974. Pulsations of domain length as support for the hypothesis of morphogenetic waves in the cambium. Acta Soc. Bot. Pol. 43: 261-271.

Hejnowicz Z., 1975. A model of morphogenetic map and clock. J. Theor. Biol. 54: 345-362.

Hejnowicz Z., Krawczyszyn J., 1969. Oriented morhogenetic phenomena in cambium of broadleaved trees. Acta Soc. Bot. Pol. 38: 547-560.

Hejnowicz Z., Romberger J.A., 1973. Migrating cambial domains and the origin of wavy grain in xylem of broadleaved trees. Amer. J. Bot. 60: 209-222.

Hejnowicz Z., Romberger J.A., 1979. The common basis of wood grain figures is the systematically changing orientation of cambial fusiform cells. Wood Sci. Technol. 13: 89-96.

Hejnowicz Z., Zagórska-Marek B.. 1974. Mechanism of changes in grain inclination in wood produced by storeyed cambium. Acta Soc. Bot. Pol. 43: 381-398.

Krawczyszyn J., 1971. Unidirectional splitting and uniting of rays in the cambium of Platanus accompanying the formation of interlocked grain in wood. Acta Soc. Bot. Pol. 40: $57-79$.

Krawczyszyn J., 1972. Movement of the cambial domain pattern and mechanism of formation of interlocked grain in Platanus. Acta Soc. Bot. Pol. 41: 443-461.

Krawczyszyn J., 1973. Domain pattern in the cambium of young Platants stems. Acta Soc. Bot. Pol. 42: 637-648.

Krawczyszyn J., Romberger J. A. 1979. Cyclical cell length changes in wood in relation to storied structure and interlocked grain. Can. J. Bot. 57: 787-79.4.

Pyszyński W., 1977. Complex wavy grain in the stem of Aesculus. Acta Soc. Bot. Pol. 46: 231-249.

Włoch W., Zagórska-Marek B., 1982. Reconstruction of storeyed cambium in the linden. Acta Soc. Bot. Pol. 51: 215-228.

Zagórska-Marek B., 1975. Growth activity of fusiform initials in storeyed cambium. Acta Soc. Bot. Pol. 44: 537-552.

Zagórska-Marek B., 1981. Ontogeneza kambium. Wiad. Bot. 25: 89-109.

Zagórska-Marek B., 1983. Anticlinal pseudotransverse divisions and intrusive elongation of fusiform initials in storeyed cambium. Maritimes Forest Research Centre, Canadian Forestry Service (in press).

\section{Czasowo zmienna częstotliwość zdarzeń $w$ domenach kambium Tilia}

\section{Streszczenie}

Przebadano próbki drewna $\mathrm{z}$ ostatnich 40 granic przyrostów rocznych, oraz kambium z pnia około 100 letniej lipy w którym występowała włóknistość zapleciona. Próbki analizowano pod względem występowania zdarzeń i zmian kierunku przebudowy komórek. Stwierdzono, że czas trwania określonego typu zdarzeń na hadanym obszarze jest różny i wynosi od 1 roku do 15 lat, a także, że istnieje duże zróżnicowanie częstotliwości zdarzeń, oraz, że są one nierównomiernie rozmieszczone. Dokładniejsza analiza wykazała, 
że zdarzenia typu $\mathrm{Z}$, a następnie $\mathrm{S}$, na kolejnych granicach przyrostów zajmują wyraźnie różne obszary, które wzajemnie się uzupełniają. Na badanych granicach przyrostów można wyróżnić więc domeny aktywne ze względu na występowanie zdarzeń i nieaktywne. $\mathrm{Na}$ badanym obszarze nastąpiła zmiana obsadzenia domen zdarzeniami, a nie zmiana typu domeny. Cały badany obszar nie jest fragmentem dużej domeny. lecz jest zbiorem małych domen spośród których w pewnym okresie obsadzone są domeny $Z$, a w innym okresie domeny S. Duża częstość występowania zdarzeń w kambium przejawia się w włóknistości falistej drewna, a amplituda falistości jest proporcjonalna do częstości zdarzeń. Jeżeli w określonym czasie przeważa aktywność domen jednego typu, to realizowany jest tylko jeden z kierunków nachylenia włóknistości na obszarze w którym ta przewaga występuje. Występowanie na przemian okresów w których przeważa jeden typ domen może prowadzić do powstania włóknistości zaplecionej w drewnie o znacznie dłuższej fali włóknistości niż wysokość pary domen. 